\title{
Does primary neoadjuvant systemic therapy eradicate minimal residual disease? Analysis of disseminated and circulating tumor cells before and after therapy
}

Sabine Kasimir-Bauer ${ }^{1}$, Ann-Kathrin Bittner ${ }^{1 *}$, Lisa König ${ }^{1}$, Katharina Reiter ${ }^{1}$, Thomas Keller², Rainer Kimmig ${ }^{1}$ and Oliver Hoffmann ${ }^{1}$

\begin{abstract}
Background: Patients with breast cancer (BC) undergoing neoadjuvant chemotherapy (NACT) may experience metastatic relapse despite achieving a pathologic complete response. We analyzed patients with $\mathrm{BC}$ before and after NACT for disseminated tumor cells (DTCs) in the bone marrow(BM); comprehensively characterized circulating tumor cells (CTCS), including stem cell-like CTCS (sICTCS), in blood to prove the effectiveness of treatment on these cells; and correlated these findings with response to therapy, progression-free survival (PFS), and overall survival (OS).

Methods: CTCS ( $n=135)$ and sICTCs ( $n=91)$ before and after NACT were analyzed using the AdnaTest BreastCancer, AdnaTest TumorStemCell, and epithelial-mesenchymal transition (QIAGEN Hannover GmbH Germany). The expression of estrogen receptor, progesterone receptor, and the resistance marker excision repair cross-complementing rodent repair deficiency, complementation group 1 (ERCC1), nuclease were studied in separate single-plex reverse transcription polymerase chain reaction experiments. DTCs were evaluated in 142 patients before and 165 patients after NACT using the pan-cytokeratin antibody A45-B/B3 for immunocytochemistry.

Results: The positivity rates for DTCS, CTCs, and sICTCS were $27 \%, 24 \%$, and $51 \%$ before and $20 \%, 8 \%$, and $20 \%$ after NACT, respectively. Interestingly, $72 \%$ of CTCS present after therapy were positive for ERCC1, and CTCs before $(p=0.005)$ and after NACT $(p=0.05)$ were significantly associated with the presence of sICTCs. Whereas no significant associations with clinical parameters were found for CTCs and sICTCS, DTCs were significantly associated with nodal status ( $p=0.03)$ and histology (0.046) before NACT and with the immunohistochemical subtype $(p=0.02)$ after NACT. Univariable Cox regression analysis revealed that age $(p=0.0065)$, tumor size before NACT $(p=0.0473)$, nodal status after NACT $(p=0.0137)$, and response to NACT $(p=0.0136)$ were significantly correlated with PFS, whereas age $(p=0.0162)$ and nodal status after NACT $(p=0.0243)$ were significantly associated with OS. No significant correlations were found for DTCs or any CTCs before and after therapy with regard to PFS and OS.

Conclusions: Although CTCs were eradicated more effectively than DTCS, CTCS detected after treatment seemed to be associated with tumor cells showing tumor stem cell characteristics as well as with resistant tumor cell populations that might indicate a worse outcome in the future. Thus, these patients might benefit from additional second-line treatment protocols including bisphosphonates for the eradication of DTCs.
\end{abstract}

Keywords: Breast cancer, Circulating tumor cells, Disseminated tumor cells, Minimal residual disease neoadjuvant therapy, Stem cells, EMT

\footnotetext{
* Correspondence: ann-kathrin.bittner@uk-essen.de

'Department of Gynecology and Obstetrics, University Hospital Essen,

University of Duisburg-Essen, Hufelandstrasse 55, D-45122 Essen, Germany

Full list of author information is available at the end of the article
} 


\section{Background}

Neoadjuvant chemotherapy (NACT) was initially used to treat locally advanced as well as inoperable tumors and now has become a standard treatment in primary breast cancer (BC). Because no difference between NACT and adjuvant treatment in terms of overall survival (OS) and the probability of disease relapse [progression-free survival (PFS)] has been demonstrated, NACT is also offered to patients with resectable tumors $[1,2]$. Thus, for most patients affected with primary BC, standard care is now NACT followed by surgical resection of the malignant tissue, offering the possibility of monitoring primary tumor response to treatment [3]. The surgical procedure might be influenced by tumor regression due to NACT. The evaluation of the effect of NACT is based on the assessment of local tumor response measured by clinical assessment; imaging modalities such as ultrasound, mammography, or magnetic resonance imaging of the breast; and postsurgery histopathological examination [4]. The primary aim of NACT is to reduce tumor size before therapy, monitor tumor response to treatment, and eradicate micrometastases.

However, although a pathological complete response (pCR) can be achieved in a range of $7.7-36.4 \%$ of cases (depending on intrinsic subtypes), showing improved long-term survival, about $20 \%$ of all patients with BC will develop metastatic relapse [5]. Relapse is often explained by early micrometastatic spread to blood, reflected by circulating tumor cells (CTCs), and to bone marrow (BM), reflected by disseminated tumor cells (DTCs) in up to $40 \%$ of the patients $[6,7]$. In this regard, the presence and persistence of CTCs and DTCs have been widely accepted as independent prognostic markers with regard to increased risk for shorter PFS and OS. Consequently, these markers have been used as a monitoring tool for adjuvant, neoadjuvant, and secondary adjuvant treatment in primary BC [8-24]. However, the detection of DTCs and CTCs has not been included in clinical routine, and therapeutic consequences according to the presence of these cells have rarely been examined. Regarding DTCs, we and others have reported that bisphosphonates, zoledronic acid, and clodronate contribute to the eradication of DTCs, even years after the first diagnosis [25-28]. Regarding CTCs, clinical studies are ongoing to evaluate targets on CTCs for additional therapeutic strategies. In this context, the DETECT III phase III trial researchers in Germany are comparing standard therapy alone with standard therapy plus human epidermal growth factor receptor 2 (HER2)targeted therapy in patients with initially HER2-negative metastatic BC and HER2-positive CTCs [29]. In addition, the Treat CTC trial investigators are evaluating the effectiveness of trastuzumab in eliminating persisting
CTCs in patients with an HER2-negative primary tumor after (neo-)adjuvant chemotherapy and surgery [30].

The reason why the detection of minimal residual disease has rarely been followed by therapeutic interventions is the broad heterogeneity of these cells, which makes therapeutic interventions difficult. Phenotyping of both cell types in primary $\mathrm{BC}$ has demonstrated a discordant estrogen receptor (ER), progesterone receptor (PR), and/or HER2 receptor status between the primary tumor and these cells and that a proportion of DTCs and CTCs are nonproliferative and stem cell-like as well as being in epithelial-mesenchymal transition (EMT), which may explain resistance to antihormonal and conventional chemotherapeutic drugs [31-40]. In this context, Creighton et al. found supported evidence that the residual breast tumor tissue cell populations surviving after letrozole or docetaxel treatment were enriched for subpopulations of cells with both tumor-initiating and mesenchymal features [41]. These data might also explain the results of the REMAGUS 02 neoadjuvant phase II study, which showed that although CTCs before therapy significantly correlated with PFS and OS, tumor response to chemotherapy was interestingly not correlated with CTC detection before and/or after NACT [42]. Similar results were also described in the neoadjuvant GeparQuattro Trial [43]. In a recently published metaanalysis summarizing the results of several prospective randomized trials of the change in CTC counts before and after NACT, researchers confirmed the loss of association between the decrease of CTC number and pCR [44]. Despite the prognostic impact of CTC counts, a comprehensive analysis of these cells, especially after NACT, would be challenging with regard to identifying predictive markers that might allow physicians to tailor treatment accordingly as well as to prevent exposure to ineffective therapies. In this regard, it has been demonstrated that a molecular method (AdnaTest; AdnaGen, Langenhagen Germany) can complement cell counting (CELLSEARCH; Janssen Diagnostics, Raritan, NJ, USA) in metastatic $\mathrm{BC}[45,46]$. In the neoadjuvant setting, to the best of our knowledge, no comprehensive characterization of CTCs has been performed until now.

We analyzed 190 patients with BC before and after NACT for DTCs in the BM and further characterized CTCs by molecular profiling, including HER2, the hormonal receptors ER and PR, and stem cell-like CTCs (slCTCs) [aldehyde dehydrogenase 1 (ALDH1) and/or EMT-like]. According to results obtained in our patients with metastatic $\mathrm{BC}$, we additionally analyzed the resistance marker excision repair cross-complementing rodent repair deficiency, complementation group 1 (ERCC1), nuclease. It was the purpose of our study to prove the effectiveness of treatment on DTCs and CTCs 
and to correlate these findings with clinical parameters, response to therapy, PFS, and OS. Besides evaluating the prognostic impact of tumor cells, one of our main goals was to identify insufficiently treated patients by comprehensive molecular characterization of CTCs for possible secondary treatment options.

\section{Methods}

\section{Patient population and patient characteristics}

The study was conducted in the Department of Gynecology and Obstetrics at the University Hospital of Essen. In total, 190 patients with diagnosed primary, nonmetastatic BC between January 2007 and June 2012 and treated with NACT were enrolled. Patient characteristics are documented in Table 1.

\section{Study design}

We conducted a retrospective, single-institution trial to determine the prognostic value of DTCs in the BM and CTCs in blood of the patients and proved the effectiveness of treatment on these cells. The median follow-up time was 54 months (range 2-93 months) for OS and 52 months (range 2-93 months) for PFS, with an OS rate of $89 \%$ and $12 \%$ for relapses.

\section{Eligibility criteria}

The eligibility criteria were histologically proven $\mathrm{BC}, \mathrm{BM}$ and blood samples obtained at the time of primary diagnosis and after neoadjuvant systemic therapy, no severe uncontrolled comorbidities or medical conditions, and no further malignancies at present or in the patient history.

Indications for NACT were: study participation for patients if comparable postoperative chemotherapy was indicated, patients with inflammatory $\mathrm{BC}$, large operable $\mathrm{BC}$ primarily requiring mastectomy and adjuvant chemotherapy with the goal of breast conservation, such as patients with nondifferentiated or poorly differentiated tumors (G3) [47].

Neoadjuvant systemic therapy was performed according to guideline-based therapeutic regimens, including chemotherapy with anthracyclines, cyclophosphamides, 5-fluorouracil, and taxanes. In addition, patients with HER2-positive tumors were treated with HER2-targeted therapy (trastuzumab or lapatinib). Seven patients were treated with vascular endothelial growth factor targeted therapy with bevacizumab. Patients were included in clinical NACT trials and treated accordingly (e.g., the LAPADO, NeoALLTO, and GeparQuinto studies [4850]). After completing NACT and surgery, patients were treated according to guidelines, including radiation, antihormonal therapy in those with hormone-responsive tumors (tamoxifen or an aromatase inhibitor), and trastuzumab therapy was completed for at least 1 year in patients with HER2 positivity [51, 52]. Additional oral clodronate therapy $(2 \times 520 \mathrm{mg}$ per day for at least 2 years) was recommended in case of DTC positivity after therapy.

\section{Response criteria}

Pathological response to therapy was defined according to the grading system of Sinn and colleagues [53] as pathological no response (regression according to Sinn $0=$ no effect), pathological partial response [pPR; regression according to Sinn $1-3$, where $1=$ resorption and tumor sclerosis, $2=$ minimal residual invasive tumor $(<0.5 \mathrm{~cm})$, and $3=$ residual noninvasive tumor only; ductal carcinoma in situ (DCIS)], and pCR (defined as no evidence of residual invasive cancer and DCIS, both in breast and axilla; regression according to Sinn $4=$ no tumor detectable).

\section{Collection and analysis of BM}

Between 10 and $20 \mathrm{ml}$ of $\mathrm{BM}$ was aspirated from the anterior iliac crests of 142 patients with primary BC before neoadjuvant systemic therapy during sentinel node biopsy or axillary lymph node dissection, as well as 165 patients during surgery of the tumor after NACT. Specimens were processed within $24 \mathrm{~h}$. All specimens were obtained after written informed consent was provided, and they were collected using protocols approved by the clinical ethics committee of University Hospital Essen $(05 / 2856)$. BM tumor cell isolation and detection were performed on the basis of recommendations for standardized tumor cell detection published by the German Consensus Group of Senology [54]. Details of the staining procedure (e.g., number of evaluated slides, controls, and cell detection) are described elsewhere [37, 55]. Briefly, BM cells were isolated from heparinized BM $(5000 \mathrm{U} / \mathrm{ml} \mathrm{BM})$ by Ficoll-Hypaque density gradient centrifugation (density $1.077 \mathrm{~g} / \mathrm{mol}$; Pharmacia \& Upjohn Diagnostics, Freiburg, Germany) at $400 \times g$ for 30 minutes. Slides were analyzed for DTCs by immunocytochemistry using the pan-cytokeratin antibody A45-B/B3. Microscopic evaluation of the slides was carried out using the ARIOL system (Applied Imaging, Grand Rapids, MI, USA) according to the International Society of Hematotherapy and Graft Engineering evaluation criteria [56].

\section{Sampling of blood}

Two $5 \mathrm{ml}$ ethylenediaminetetraacetic acid blood samples were collected for isolation of CTCs before the application of therapeutic substances with an S-Monovette (Sarstedt AG \& Co., Nümbrecht, Germany) and stored at $4{ }^{\circ} \mathrm{C}$ until further examination. The samples were processed immediately or at latest $4 \mathrm{~h}$ after blood withdrawal. 
Table 1 Patient characteristics

\begin{tabular}{|c|c|}
\hline Characteristics & Data \\
\hline Total number of patients & 190 \\
\hline Age, yr & $51(18-84)$ \\
\hline \multicolumn{2}{|l|}{ Menopausal status } \\
\hline Premenopausal & $87(46 \%)$ \\
\hline Perimenopausal & $24(13 \%)$ \\
\hline Postmenopausal & 79 (42 \%) \\
\hline \multicolumn{2}{|l|}{ Histologic findings } \\
\hline Ductal & $140(74 \%)$ \\
\hline Lobular & $22(12 \%)$ \\
\hline Other & $24(13 \%)$ \\
\hline Unknown & $4(2 \%)$ \\
\hline \multicolumn{2}{|l|}{ Tumor grading } \\
\hline G1 & 13 (7 \%) \\
\hline $\mathrm{G} 2$ & $85(45 \%)$ \\
\hline G3 & $88(46 \%)$ \\
\hline Unknown & $4(2 \%)$ \\
\hline \multicolumn{2}{|l|}{ Tumor size before NACT } \\
\hline cT1a-cT1c & $46(24 \%)$ \\
\hline cT2 & $111(58 \%)$ \\
\hline Above $\mathrm{CT} 2$ & $29(15 \%)$ \\
\hline Unknown & $4(2 \%)$ \\
\hline
\end{tabular}

Tumor size after NACT

урто(is)

урT1а-урT1с

ypT2

Above ypT2

Unknown

Nodal status before NACT

CNO

$\mathrm{cN} 1$

$\mathrm{cN} 2, \mathrm{cN} 3$

Unknown

Nodal status after NACT

yNO

yN1

yN2,N3

Unknown

Estrogen receptor

Positive

Negative

Unknown
$46 / 177(26 \%)$

$71 / 177(40 \%)$

$47 / 177(27 \%)$

13/177 (7\%)

$13 / 190$

$94(49 \%)$

$83(44 \%)$

$10(5 \%)$

$3(2 \%)$

$116 / 180(64 \%)$

$48 / 180(27 \%)$

16/180 (9\%)

$10 / 190$

$131(69 \%)$

$58(31 \%)$

$1(1 \%)$
Table 1 Patient characteristics (Continued)

\begin{tabular}{|c|c|}
\hline \multicolumn{2}{|l|}{ Progesterone receptor } \\
\hline Positive & $116(61 \%)$ \\
\hline Negative & 73 (38 \%) \\
\hline Unknown & $1(1 \%)$ \\
\hline \multicolumn{2}{|l|}{ HER2 status } \\
\hline Positive & $56(29 \%)$ \\
\hline Negative & $133(70 \%)$ \\
\hline Unknown & $1(1 \%)$ \\
\hline \multicolumn{2}{|l|}{ Tumor subtype (IHC) } \\
\hline ER-, PR-, HER2- & $36(19 \%)$ \\
\hline ER-, PR-, HER2+ & $15(8 \%)$ \\
\hline ER+/PR+, HER2- & 97 (51 \%) \\
\hline $\mathrm{ER}+, \mathrm{PR}+, \mathrm{HER} 2+$ & $41(22 \%)$ \\
\hline Unknown/n.a. & $1(1 \%)$ \\
\hline \multicolumn{2}{|l|}{ Pathological response } \\
\hline Complete response & 37/176 (21\%) \\
\hline Partial response & 127/176 (72 \%) \\
\hline No response & 12/176 (7 \%) \\
\hline Unknown & $14(7 \%)$ \\
\hline \multicolumn{2}{|l|}{ DTC positive } \\
\hline Before therapy & 38/142 (27 \%) \\
\hline After therapy & 33/165 (20 \%) \\
\hline \multicolumn{2}{|l|}{ CTC positive } \\
\hline Before therapy & 32/135 (24 \%) \\
\hline After therapy & 11/133 (8 \%) \\
\hline \multicolumn{2}{|l|}{ sICTC positive } \\
\hline Before therapy & 46/91 (51\%) \\
\hline After therapy & 18/90 (20 \%) \\
\hline \multicolumn{2}{|l|}{ DTC and/or CTC positive } \\
\hline Before therapy & 59/136 (43\%) \\
\hline After therapy & $44 / 140(34 \%)$ \\
\hline \multicolumn{2}{|l|}{ DTC and/or sICTC-pos. } \\
\hline Before therapy & 74/107 (69 \%) \\
\hline After therapy & 48/103 (47 \%) \\
\hline \multicolumn{2}{|c|}{ CTC and/or sICTC positive } \\
\hline Before therapy & $57 / 92(62 \%)$ \\
\hline After therapy & 25/89 (28 \%) \\
\hline \multicolumn{2}{|l|}{ Survival } \\
\hline OS & $54 \mathrm{mo}(2-93 \mathrm{mo})$ \\
\hline Alive & 169 (89 \%) \\
\hline Dead & $19(10 \%)$ \\
\hline Unknown & $2(1 \%)$ \\
\hline PFS & $52 \mathrm{mo}(2-93 \mathrm{mo})$ \\
\hline
\end{tabular}


Table 1 Patient characteristics (Continued)

\begin{tabular}{ll}
\hline Recurrence & \\
Alive without relapse & $135(71 \%)$ \\
Relapse & $22(12 \%)$ \\
Unknown & $33(17 \%)$
\end{tabular}

CTC circulating tumor cell, DTC disseminated tumor cell, ER estrogen receptor, HER2 human epidermal growth factor receptor 2, IHC immunhistochemstry, NACT neoadjuvant chemotherapy, OS overall survival, PFS progression-free survival, $P R$ progesterone receptor, sICTC stem cell-like circulating tumor cell Data are presented as median (range) or number (\%)

\section{Selection, detection, and evaluation of CTCs}

Two $5 \mathrm{ml}$ of blood before $(n=135$ patients) and after $(n$ = 133 patients) therapy were analyzed for CTCs with AdnaTest BreastCancer (QIAGEN Hannover GmbH) for the detection of transcripts of epithelial cell adhesion molecule (EpCAM); mucin 1, cell surface associated (MUC1); HER2; and $\beta$-actin. Expression of ER, $\mathrm{PR}$, and ERCC1 was assessed in an additional reverse transcription polymerase chain reaction (RT-PCR) experiment. Establishment and validation of this assay are described in detail elsewhere [57, 58]. Briefly, all samples underwent immunomagnetic enrichment using the AdnaTest BreastCancerSelect (QIAGEN, Hannover $\mathrm{GmbH}$ ). followed by RNA isolation and subsequent gene expression analysis by multiplex RTPCR in separated tumor cells using the AdnaTest BreastCancerDetect (QIAGEN Hannover, GmbH). The primers generated fragments of the following sizes: GA 733-2, 395 bp; MUC1, 293 bp; HER2, 270 bp; PR, 270 bp; ER, 305 bp; ERCC1, 366 bp; and actin, 114 bp. Visualization of the PCR fragments was carried out with a 2100 Bioanalyzer using DNA 1000 LabChips (Agilent Technologies, Waldbronn, Germany) and the Expert software package (version B.02.03.SI307; Agilent Technologies).

\section{AdnaTest TumorStemCell and AdnaTest EMT}

Both the AdnaTest TumorStemCell and AdnaTest EMT require the enrichment of CTCs from $5 \mathrm{ml}$ of blood using AdnaTest BreastCancerSelect before a single-plex PCR assay to analyze ALDH1 and a multiplex PCR assay to analyze EMT markers and actin as an internal control. In total, the analysis of 148 healthy controls resulted in a specificity of $97 \%$ and a sensitivity of $96 \%$ for this test procedure, which is comparable to our previously published data in smaller cohorts [33, 34]. The primers generate fragments of the following sizes: ALDH1, 165 bp; AKT2, 306 bp; Twist-related protein 1 (TWIST1), $203 \mathrm{bp}$; phosphoinositide 3-kinase alpha (PI3K $\alpha), 595$ bp; and $\beta$-actin, 119 bp.

\section{Evaluation of data established for CTCs}

The test result is considered positive if a PCR fragment of at least one tumor-associated transcript (MUC1,
GA773-2, or HER2) is clearly detected. Using the software package for evaluation of the data on the Agilent 2100 Bioanalyzer, we found that peaks with a concentration $>0.15 \mathrm{ng} / \mu \mathrm{l}$ were positive for the transcripts of GA733-2, MUC1, and HER2. Peaks with concentrations $>0.60 \mathrm{ng} / \mu \mathrm{l}$ were positive for the ER transcript and $>0.20 \mathrm{ng} / \mu \mathrm{l}$ were positive for the ERCC1 transcript. PR expression is considered positive when the transcript is detected without applying any cutoff. The cutoff values for the EMT markers and ALDH1 are $0.2 \mathrm{ng} / \mu \mathrm{l}$ for AKT2, $0.15 \mathrm{ng} / \mu \mathrm{l}$ for TWIST1, $0.25 \mathrm{ng} / \mu \mathrm{l}$ for PI3K $\alpha$, and $0.15 \mathrm{ng} / \mu \mathrm{l}$ for ALDH1.

\section{Immunohistochemical analysis of the primary tumor}

For each of the 190 patients, the tumor type, TNM stage, and grade were assessed according to the World Health Organization classification of breast tumors [59] and the Sixth Edition of the TNM classification system [60]. ER and PR status were routinely determined by immunohistochemistry (IHC) in the pathology departments of each university hospital. The HercepTest score (Dako, Glostrup, Denmark) for the expression of HER2 was determined, and fluorescence in situ hybridization analysis was performed in cases of $2+$ staining, as described elsewhere [61].

\section{Statistical analysis}

The statistical analysis was performed using $\mathrm{SAS}^{\bullet} 9.2$ software (SAS Institute, Cary, NC, USA). Summary statistics are presented as counts and percentages in the case of categorically scaled measures and as mean, median, standard deviation, and range in the case of continuously scaled variables. All cases with any available information were analyzed, and no imputation of missing information was foreseen.

The statistical analysis of relationships among the variables was performed in an exploratory way, starting with description by contingency tables ( $x^{2}$ test or Fisher's exact test for categorically scaled variables) or comparison of distributions (Mann-Whitney $U$ test for continuously scaled variables). In parallel, univariable logistic regression models regarding binary outcome (yes or no) by factor were analyzed. Univariable Cox proportional hazards models were applied to investigate the influence of possible influencing variables on OS and PFS. In case of significant findings, Kaplan-Meier analyses were performed to create survival curves. The resulting odds ratio (OR) and hazard ratio (HR) are reported along with their $95 \%$ confidence interval (CI) and $p$ values. An $\alpha$ level of 0.05 was used, whereby an adjustment for multiple testing was not foreseen. Because of the limited sample size of patients with available cell count information and missing significant effects for cell counts on outcome measures in 
univariable analyses, a multivariable analysis was not performed.

\section{Results}

\section{Patient characteristics}

Clinical data are shown in detail in Table 1. The exact numbers of patients who had the different tests before and after NACT are shown in Additional file 1: Fig. S1. A total of 190 patients were included in the study. The median age of the patients was 51 years (range 18-84 years), and most women were either premenopausal $(n=87)$ or postmenopausal $(n=79)$. The predominant histologic subtype was invasive ductal carcinoma $(n=140)$, and most patients had grade II $(n=85)$ and grade III $(n=88)$ tumors. Tumor size before therapy was cT1a-cT1c in 46 patients (24\%), cT2 in 111 patients (58 \%), and above cT2 in 29 patients (15\%). After therapy, tumor size was available in 177 patients, resulting in ypT0 tumors in $26 \%$, ypT1a-ypT1c tumors in $40 \%$, and ypT2 tumors in $27 \%$ of cases. Twelve patients had tumors above ypT2. Before therapy, 94 patients were classified as node-negative. All other patients were $\mathrm{cN} 1 \quad(n=83)$ and $\mathrm{cN} 2$ or $\mathrm{cN} 3$ $(n=10)$. After therapy, nodal status was available in 180 patients, resulting in 116 (64 \%) node-negative and $64(37 \%)$ node-positive patients. ER positivity was observed in in $69 \%(n=131)$ and PR positivity in $61 \%(n=116)$ of the tumors. In $29 \%(n=56)$ of the cases, HER2 was overexpressed. Classifying tumors in subtypes on the basis of their receptor status, $51 \%$ $(n=97)$ of the tumors were ER- and/or PR-positive and HER2-negative, $19 \%(n=36)$ were triple-negative (ER -/PR-/ HER2-), and $8 \%(n=15)$ of the tumors expressed only HER2 (ER-/PR-/HER2+). Response to therapy could be evaluated in 176 patients, resulting in ratios of $93 \%$ responders ( $21 \%$ complete response, $72 \%$ partial response) and $7 \%$ nonresponders.

\section{Detection of DTCs, CTCs, and sICTCs before and after NACT}

DTCs were found in 38 (27\%) of 142 patients before and in $33(20 \%)$ of 165 patients after therapy (Table 1$)$. In 118 patients, DTC status could be evaluated before and after NACT, resulting in positivity rates of $26 \%$ before (31 of 118 patients) and $19 \%$ (22 of 118 patients) after therapy. In 73 patients, no DTCs were detected at any time point, while 8 patients had persisting DTCs. Twenty-three of the thirty-one DTC-positive patients before NACT turned negative after chemotherapy, and fourteen patients with a negative DTC status before therapy had a positive DTC status after chemotherapy (Table 2).

The detailed analysis for the evaluation of CTCs is illustrated in Fig. 1. Before therapy, CTCs were detected
Table 2 Paired analysis of tumor cells before and after NACT

\begin{tabular}{llll}
\hline & \multicolumn{2}{l}{ Tumor cells after NACT } & \\
\cline { 2 - 3 } Tumor cells before NACT & Negative & Positive & Total \\
\hline Total & 96 & $22(19 \%)$ & 118 \\
DTC-negative & 73 & 14 & 87 \\
DTC-positive & 23 & 8 & $31(26 \%)$ \\
Total & 82 & $10(11 \%)$ & 92 \\
CTC-negative & 58 & 9 & 67 \\
CTC-positive & 24 & 1 & $25(27 \%)$ \\
Total & 39 & $9(19 \%)$ & 48 \\
SICTC-negative & 18 & 1 & 19 \\
SICTC-positive & 21 & 8 & $29(60 \%)$
\end{tabular}

CTC circulating tumor cell, DTC disseminated tumor cell, NACT neoadjuvant chemotherapy

in $32(24 \%)$ of 135 of the patients expressing EpCAM (19\%), MUC-1 (41 \%), HER2 (75\%), ER (19\%), PR (6\%), and ERCC1 (63\%). After therapy, 11 (8\%) of 133 of the patients were still positive for CTCs expressing EpCAM, MUC1, and HER2 (each $45 \%$ ); ER (18 \%); PR (0 \%); and ERCC1 (72\%). slCTCs were detected in 46 (51\%) of 91 of the patients before and in 18 (20\%) of 90 of the patients after therapy. Further, $47 \%$ of the patients were positive for at least one of the EMT markers before and $14 \%$ after therapy. For ALDH1, the values were $17 \%$ and $12 \%$, respectively. Interestingly, after therapy, $50 \%$ of the ERCC1-positive CTCs were also positive for ALDH1 and for at least one EMT marker.

Before therapy, 59 (43 \%) of 136 patients were positive for DTCs and/or CTCs, 74 (69\%) of 107 were positive for DTCs and/or slCTCs, and 57 (62\%) of 92 were positive for CTCs and/or slCTCs. After therapy, the corresponding values were $34 \%$ (44 of 140 patients), $47 \%$ (48 of 103 patients), and $28 \%$ (25 of 89 patients), respectively. The presence of CTCs before (OR 4.200, $95 \%$ CI $1.549-11.389, p=0.005$ ) and after therapy (OR 0.688, $95 \%$ CI $0.177-2.676, p=0.05)$ was significantly associated with the presence of slCTCs (Tables 3 and 4).

In 92 patients, CTC status could be evaluated before and after NACT. We found positivity rates of $27 \%$ before (25/92 patients) and $11 \%$ (10/92 patients) after therapy. Interestingly, CTCs were eradicated in 24 of 25 CTC-positive patients before therapy, while only 1 patient had persisting CTCs and $9(13 \%)$ of 67 patients had a switch from negative to positive CTC status (Table 2). In addition, the switch from CTC-positive before to CTC-negative after NACT appeared more often in post- and perimenopausal women than in premenopausal women $(p=0.0499)$.

slCTC status before and after NACT was available in 48 patients, with positivity rates of $60 \%$ (29 of 48 patients) before and $19 \%$ (9 of 48 patients) after therapy. Eight patients had persisting slCTCs, while eighteen 


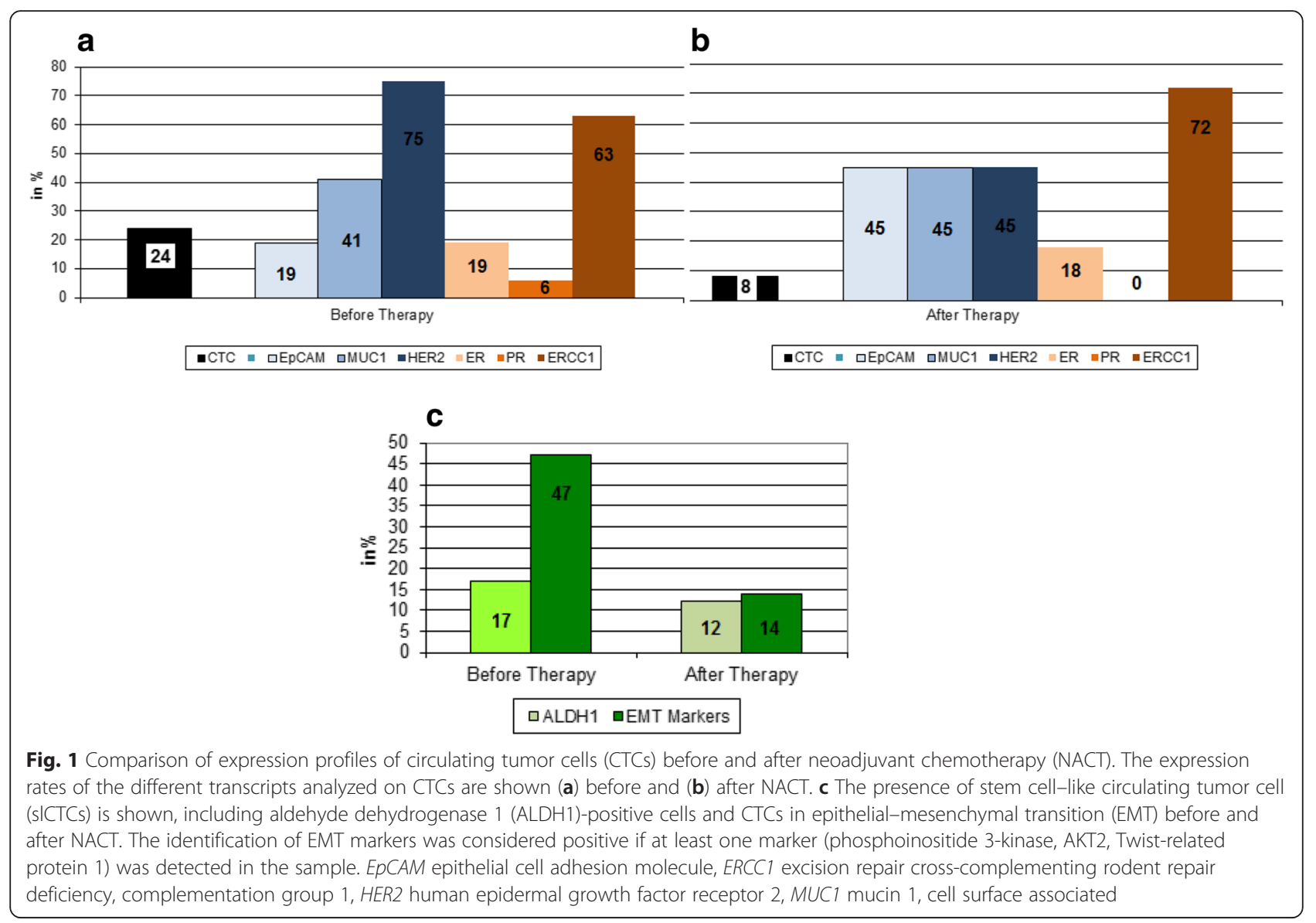

patients were negative/negative, 21 patients were positive/negative, and only one patient was negative/positive (Table 2). Furthermore, the eradication of slCTCs was rarer the bigger the tumor size $(p=0.044)$.

\section{Correlation of tumor cells before and after NACT with clinical characteristics}

The correlation between the presence of tumor cells and clinical characteristics before and after therapy is shown in Tables 2 and 3 . Whereas no significant associations with clinical parameters were found for CTCs and slCTCs before and after therapy, DTCs were significantly associated with nodal status (OR $0.335,95 \%$ CI $0.143-0.785, p=0.03$ for N0 vs N1) and histology (OR 2.926, $95 \%$ CI 1.001-8.556, $p=0.046$ for ductal vs lobular; OR 0.125, $95 \%$ CI 0.021-0.732, $p=$ 0.023 for lobular vs. other) before therapy and the IHC subtype (OR 3.954, $95 \%$ CI 1.564-9.997, $p=0.02$ for triple-negative vs. ER and/or PR-positive but HER2negative). Although no significant correlations were observed for response and slCTCs before therapy, logistic regression identified a significant relationship between slCTCs and the group of complete responders vs. no remission (OR 0.091, 95 \% CI 0.009-0.880, $p=0.04$ ).

\section{Survival analysis}

As shown in Table 1, the median follow-up time for PFS was 52 months (range 2-93 months), and for OS it was 54 months (range 2-93 months). The OS (not BCspecific) rate was $89 \%$. Relapses occurred in $12 \%$ of cases, 3 patients had local recurrence, 16 patients had a distant recurrence, and 3 patients had both local and distant recurrence. Univariable Cox regression analysis revealed age $(p=0.0065)$, tumor size before $(p=0.0473)$, nodal status $(p=0.0137)$ after NACT, and response to NACT $(p=0.0136)$ were also significantly correlated with PFS, whereas age $(p=0.0162)$ and nodal status after NACT $(p=0.0243)$ were significantly associated with OS (Table 5). No significant correlations were found for DTCs or any CTCs before and after therapy with regard to PFS and OS (Figs. 2 and 3). In addition, all combinations tested between the presence of DTCs and/or any CTCs, as well as their change before and after therapy, and PFS and OS did not show any significant results (data not shown).

\section{Discussion}

Primary systemic NACT in BC is considered to convert inoperable tumors to operable primary tumors and is 
Table 3 Correlation between clinical data and DTCS, CTCS, and sICTCs before therapy

\begin{tabular}{|c|c|c|c|c|c|c|c|c|c|}
\hline & Total & DTC-positive, $n$ (\%) & $p$ Value & Total & CTC-positive, $n$ (\%) & $p$ Value & Total & sICTC-positive (\%) & $p$ Value \\
\hline Tumor size & 139 & $37(27)$ & & 132 & $31(23)$ & & 89 & $44(49)$ & \\
\hline cT1 & 32 & $5(16)$ & 0.27 & 32 & $10(31)$ & 0.26 & 26 & $15(58)$ & 0.56 \\
\hline cT2 & 86 & $25(29)$ & & 81 & $19(23)$ & & 53 & $25(47)$ & \\
\hline Above cT2 & 21 & $7(33)$ & & 19 & $2(11)$ & & 10 & $4(40)$ & \\
\hline Nodal status & 141 & $38(27)$ & & 134 & $32(24)$ & & 90 & $45(50)$ & \\
\hline $\mathrm{CNO}$ & 77 & $28(36)$ & 0.03 & 74 & $21(28)$ & 0.62 & 46 & $24(52)$ & 0.44 \\
\hline $\mathrm{cN} 1$ & 56 & $9(16)$ & & 53 & $11(21)$ & & 39 & $20(51)$ & \\
\hline $\mathrm{cN} 2, \mathrm{cN} 3$ & 8 & $1(13)$ & & 7 & $0(0)$ & & 5 & $1(20)$ & \\
\hline Histology & 140 & $37(26)$ & & 133 & $32(24)$ & & 90 & $45(50)$ & \\
\hline Ductal & 106 & $27(25)$ & 0.046 & 99 & $22(22)$ & 0.70 & 67 & $33(49)$ & 0.80 \\
\hline Lobular & 16 & $8(50)$ & & 17 & $5(29)$ & & 12 & $7(58)$ & \\
\hline Others & 18 & $2(11)$ & & 17 & $5(29)$ & & 11 & $5(45)$ & \\
\hline Grade & 139 & $38(27)$ & & 132 & $32(24)$ & & 89 & $44(49)$ & \\
\hline I & 9 & $2(22)$ & 0.87 & 12 & $0(0)$ & 0.31 & 5 & $3(60)$ & \\
\hline$\|$ & 65 & $19(29)$ & & 59 & $12(20)$ & & 40 & $17(43)$ & 0.49 \\
\hline III & 65 & $17(26)$ & & 61 & $20(33)$ & & 44 & $24(55)$ & \\
\hline ER status & 141 & $38(27)$ & & 134 & $32(24)$ & & 90 & $45(50)$ & \\
\hline Negative & 43 & $8(17)$ & 0.14 & 41 & $8(20)$ & 0.43 & 24 & $11(46)$ & 0.63 \\
\hline Positive & 98 & $30(31)$ & & 93 & $24(26)$ & & 66 & $34(52)$ & \\
\hline PR status & 141 & $38(27)$ & & 134 & $32(24)$ & & 90 & $45(50)$ & \\
\hline Negative & 60 & $14(23)$ & 0.41 & 56 & $13(23)$ & 0.88 & 39 & $19(49)$ & 0.83 \\
\hline Positive & 81 & $24(30)$ & & 78 & $19(24)$ & & 51 & $26(51)$ & \\
\hline
\end{tabular}

CTC circulating tumor cell, DTC disseminated tumor cell, ER estrogen receptor, $P R$ progesterone receptor, sICTC stem cell-like circulating tumor cell

undertaken to improve surgical options. Furthermore, NACT reflects the tumor response to treatment and allows a more individual therapeutic concept. Response to NACT has been associated with improved PFS and OS. The OS rate in our sample was $89 \%$, as compared with an overall OS rate of $87 \%$ in Germany [62]. Taking into account that we exclusively had a high-risk patient cohort undergoing NACT, we documented a better OS than the overall OS rate of patients with BC in Germany, containing high- as well as low-risk patients. Furthermore, we showed a significant correlation of response to NACT with regard to PFS when patients with pCR or pPR were compared with nonresponders. For OS, no significant associations were found, probably due to the fact that the observation period was still too short. However, some patients experienced relapse, even those having achieved a pCR, as recently published [63]. This indicates that the disease is able to persist in secondary organs such as the BM, which might have spread tumor cells into the circulation. We demonstrate that, although CTCs were eradicated more effectively than DTCs, CTCs detected after treatment seemed to be associated with tumor cells showing tumor stem cell characteristics as well as resistant tumor cell populations, which might indicate worse outcome in the future. These findings underline our assumption that CTCs, probably circulating from reservoirs in the lung or liver, might be a highrisk indicator for already ongoing metastasis not limited to bone metastasis.

Thus, these patients might benefit from additional second-line treatment protocols for the eradication of minimal residual disease. However, after a median follow-up time of nearly 5 years, no significant correlations were found for DTCs, CTCs, and slCTCs as well as for their changes before and after therapy with regard to PFS and OS.

\section{Disseminated tumor cells}

DTCs have been analyzed mainly after NACT, with a detection rate of $40-50 \%$ but demonstrating that $30 \%$ of the detected cells were apoptotic [21, 64]. In only one study have researchers analyzed these cells before and after NACT, showing positivity rates of $21 \%$ and $16 \%$, respectively, which is quite in accord with our data showing $27 \%$ positivity before and $19 \%$ after NACT, respectively [11]. Interestingly, 14 of 87 patients with a negative DTC status before therapy switched to a positive DTC status after chemotherapy. We can only 
Table 4 Correlation between clinical data and DTCs, CTCs, and sICTCs after therapy

\begin{tabular}{|c|c|c|c|c|c|c|c|c|c|}
\hline & Total & DTC-positive, $n \%$ & $p$ Value & Total & CTC-positive, $n \%$ & $p$ Value & Total & slCTC-positive, $n \%$ & $p$ Value \\
\hline Tumor size & 163 & $33(20)$ & & 131 & $11(8)$ & & 88 & $18(20)$ & \\
\hline ypTis, ypTo & 43 & $12(28)$ & 0.25 & 36 & $3(8)$ & 0.86 & 21 & $3(14)$ & 0.50 \\
\hline урT1а & 15 & $2(13)$ & & 13 & $0(0)$ & & 12 & $1(8)$ & \\
\hline ypT1b, ypT1c & 52 & $6(12)$ & & 40 & $4(10)$ & & 26 & $5(19)$ & \\
\hline ypT2 & 41 & $11(27)$ & & 31 & $2(6)$ & & 23 & $7(30)$ & \\
\hline Above ypT2 & 12 & $2(17)$ & & 11 & $2(18)$ & & 6 & $2(33)$ & \\
\hline Nodal status & 163 & $33(20)$ & & 131 & $11(8)$ & & 88 & $18(20)$ & \\
\hline yNo & 103 & $26(25)$ & 0.13 & 83 & $6(7)$ & 0.17 & 56 & $11(20)$ & 0.73 \\
\hline yN1 & 44 & $5(11)$ & & 35 & $2(6)$ & & 22 & $4(18)$ & \\
\hline yN2, yN3 & 46 & $2(13)$ & & 13 & $3(23)$ & & 10 & $3(30)$ & \\
\hline Histology & 163 & $33(20)$ & & 131 & $11(8)$ & & 89 & $18(20)$ & \\
\hline Ductal & 122 & $28(23)$ & 1.00 & 94 & $9(10)$ & 0.75 & 66 & $14(21)$ & 0.83 \\
\hline Lobular & 21 & $5(24)$ & & 19 & $1(5)$ & & 9 & $2(22)$ & \\
\hline Other & 20 & $0(0)$ & & 18 & $1(6)$ & & 14 & $2(14)$ & \\
\hline Grade & 162 & $32(20)$ & & 130 & $11(8)$ & & 88 & $18(20)$ & \\
\hline I & 11 & $2(18)$ & 0.95 & 9 & $2(22)$ & 0.35 & 3 & $1(33)$ & 0.85 \\
\hline$\|$ & 72 & $15(21)$ & & 55 & $4(7)$ & & 39 & $8(21)$ & \\
\hline III & 79 & $15(19)$ & & 66 & $5(8)$ & & 46 & $9(20)$ & \\
\hline ER status & 165 & $33(20)$ & & 133 & $11(8)$ & & 90 & $18(20)$ & \\
\hline Negative & 52 & $14(27)$ & 0.13 & 43 & $1(2)$ & 0.12 & 30 & $3(10)$ & 0.11 \\
\hline Positive & 113 & $19(17)$ & & 90 & $10(11)$ & & 60 & $15(25)$ & \\
\hline PR status & 165 & $33(20)$ & & 133 & $11(8)$ & & 90 & $18(20)$ & \\
\hline Negative & 62 & $17(27)$ & 0.07 & 49 & $2(4)$ & 0.20 & 35 & $5(14)$ & 0.28 \\
\hline Positive & 103 & $16(16)$ & & 84 & $9(11)$ & & 55 & $13(24)$ & \\
\hline
\end{tabular}

CTC circulating tumor cell, DTC disseminated tumor cell, ER estrogen receptor, $P R$ progesterone receptor, sICTC stem cell-like circulating tumor cell

speculate and hypothesize that these patients probably were DTC-positive before therapy and that DTCs probably had undergone EMT and lost their epithelial character, which allowed them to travel to metastatic sites without being affected by conventional treatment [65].

Furthermore, DTCs in our patients were significantly associated with nodal status before and after NACT as well as with the histology- and IHC-determined subtype before NACT, while no significant correlations could be documented for PFS and OS, which is in contrast to the results obtained in the above-mentioned studies. The fact that DTCs persist after treatment and are associated with worse outcome has already been described and is explained by a clinically significant biological heterogeneity,

Table 5 Univariable Cox regression analysis of survival

\begin{tabular}{|c|c|c|c|c|}
\hline & \multicolumn{2}{|l|}{ PFS } & \multicolumn{2}{|l|}{ OS } \\
\hline & $\mathrm{HR}$ & $p$ Value & $\mathrm{HR}$ & $p$ Value \\
\hline Age & & 0.0065 & & 0.0162 \\
\hline \multicolumn{5}{|l|}{ Tumor size before therapy } \\
\hline cT1 vs. cT2 & $7.621(1.024-56.707)$ & 0.0473 & n.s. & \\
\hline \multicolumn{5}{|l|}{ Nodal status after therapy } \\
\hline yNo vs. yN2, yN3 & $3.377(1.283-8.890)$ & 0.0137 & $4.104(1.201-14.027)$ & 0.0243 \\
\hline \multicolumn{5}{|l|}{ Response to NACT } \\
\hline Partial response vs. no response & 3.107 (1.157-8.344) & 0.0245 & n.a. & \\
\hline Complete response vs. no response & $16.974(1.971-145.174)$ & 0.0099 & n.s. & \\
\hline
\end{tabular}




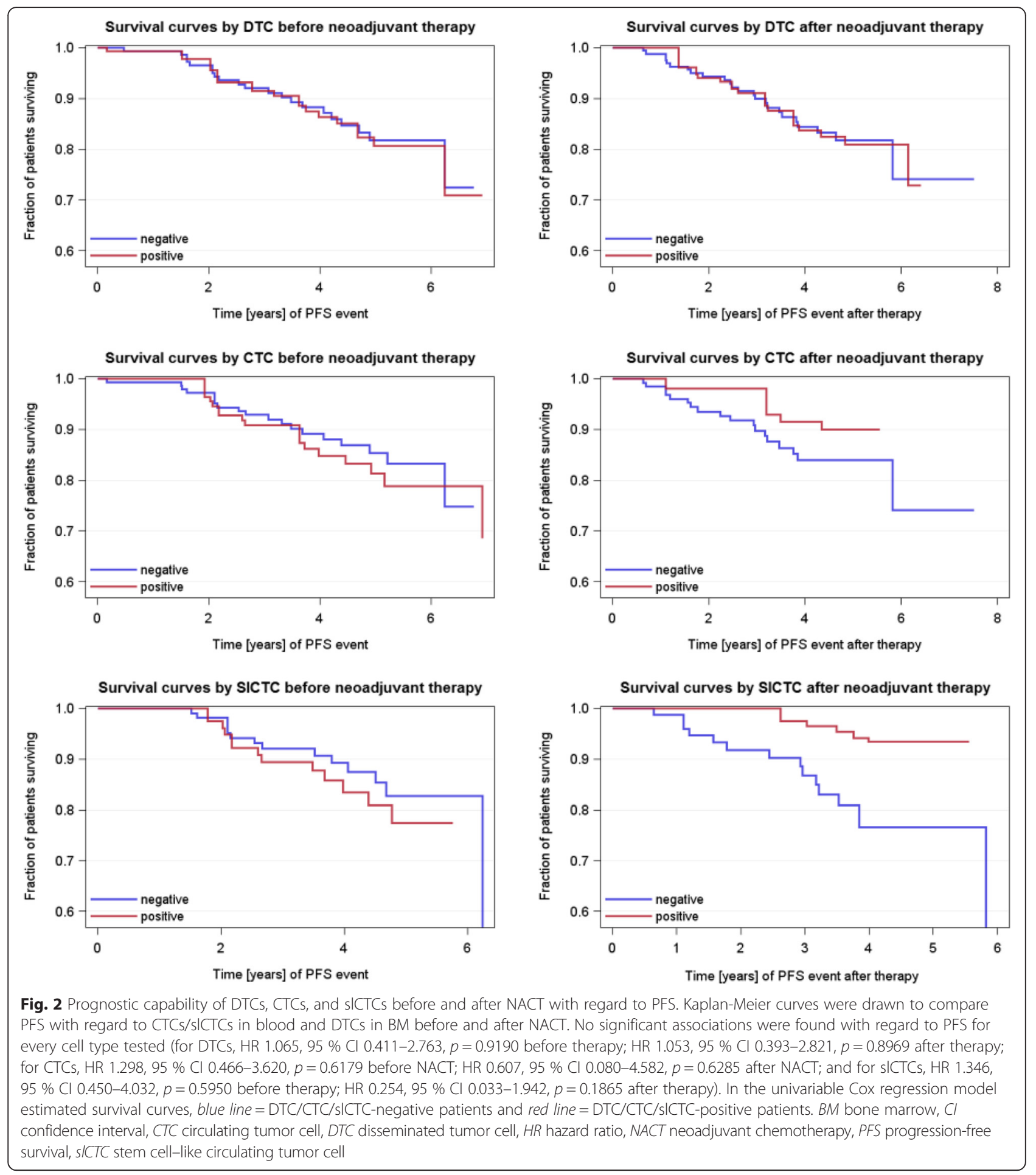

most likely due to phenotypical changes, EMT and stem cell characteristics, and altered genomic characteristics between DTCs, CTCs, and the primary tumor [9-11, 32, 35, 66-70]. One treatment option for DTCs has been demonstrated by Naume et al., who administered six cycles of docetaxel as secondary treatment in DTC-positive patients after first-line therapy with fluorouracil, epirubicin, and cyclophosphamide, resulting in better survival of these patients [71]. We did not further characterize DTCs; thus, we can only speculate that residual cells might have stem cell characteristics in some patients. However, we did 

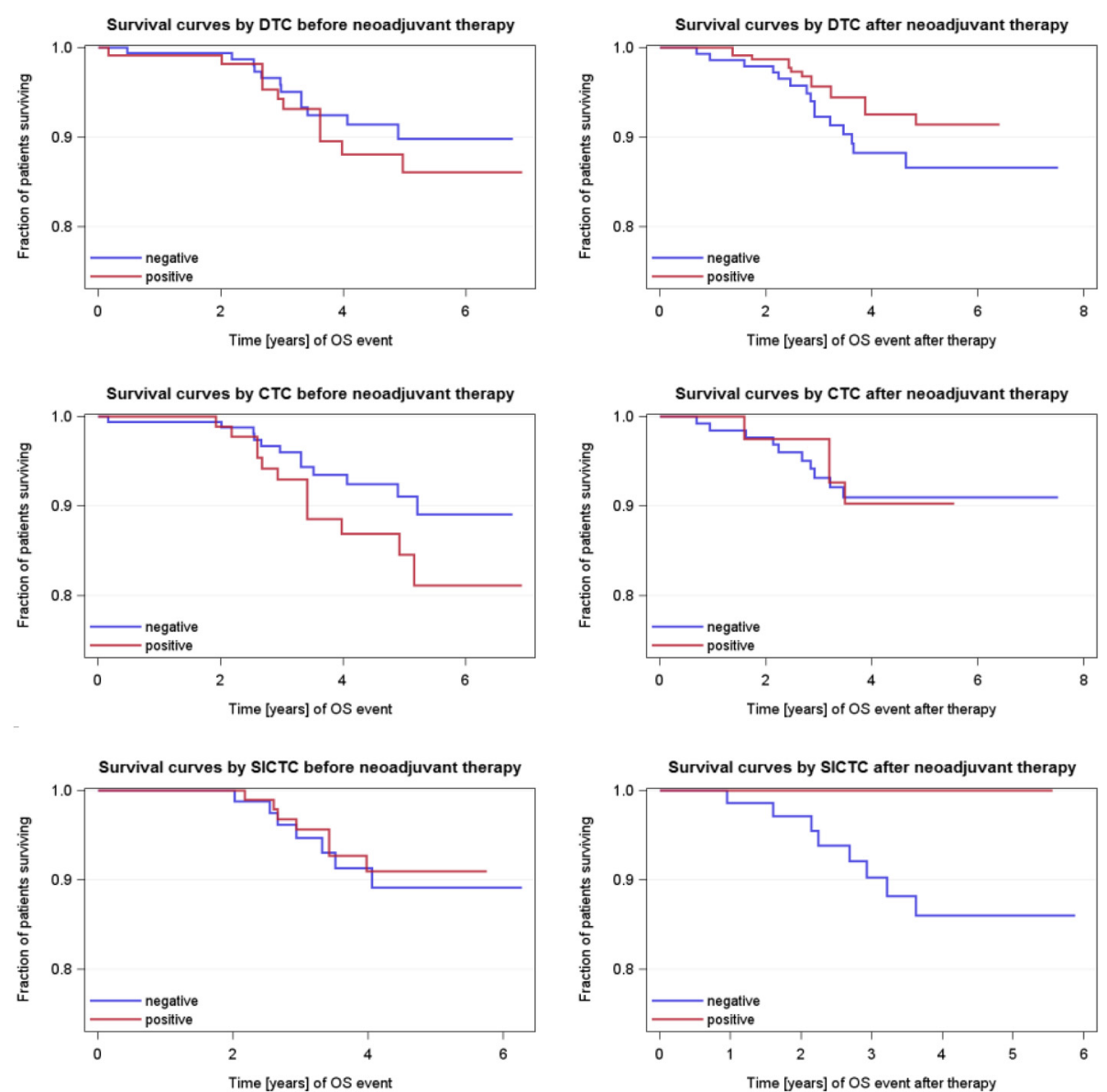

Fig. 3 Prognostic capability of DTCs, CTCS, and sICTCs before and after NACT with regard to OS. Estimated survival curves adjusted for cell type status were drawn to compare OS with regard to CTCS/sICTCs in blood and DTCs in BM before and after NACT. No significant associations were found with regard to OS for every cell type tested [for DTCS, HR 1.404, $95 \%$ Cl 0.422-4.664, $p=0.5800$ before therapy; HR 0.628, $95 \%$ Cl 0.142-2.786, $p=0.5406$ after therapy; for CTCS, HR 1.795, $95 \%$ Cl 0.538-5.987, $p=0.3414$ before NACT; HR 1.083, $95 \%$ Cl 0.137-8.550, $p=0.9400$ after NACT; for sICTCS, HR 0.830, $95 \%$ Cl 0.186-3.710, $p=0.8068$ before and after therapy; and not applicable (no events for slCTC-positive patients)]. BM bone marrow, Cl confidence interval, CTC circulating tumor cell, DTC disseminated tumor cell, HR hazard ratio, NACT neoadjuvant chemotherapy, OS overall survival, s/CTC stem cell-like circulating tumor cell

not see any negative prognostic effect of DTCs before and/or after NACT with regard to PFS and OS after a median follow-up of nearly 5 years, which is in accord with our other published adjuvant BC studies, where we demonstrated that the intake of clodronate in case of DTC positivity was able to eradicate DTCs even years after the first diagnosis [26, 72]. Thus, clodronate intake was also offered to DTC-positive patients in this study. However, it is still unknown whether bisphosphonates are also able to eradicate stem cell-like DTCs present among DTCs in the BM. The fact that stem cell-like and EMT-like cells, probably circulating from reservoirs other than the BM (e.g. liver, lung), were present in blood samples before and after therapy makes the hypothesis that DTCs with stem cell-like characteristics are eradicated by bisphosphonates more or less unlikely.

\section{Circulating tumor cells}

CTCs have been suggested to be potential surrogate markers for minimal residual disease, the precursor of metastatic disease. There is increasing evidence that CTCs could be a strong predictive biomarker of response to NACT because BM is too invasive and painful for monitoring purposes. Unfortunately, a recently published meta-analysis confirmed that, although CTCs before NACT significantly correlated with reduced PFS in some studies, the change (decrease or increase) in CTC numbers during NACT in patients with locally advanced $\mathrm{BC}$ was not associated with $\mathrm{pCR}$, and a decrease in CTC counts after NACT did not indicate that patients had an improved response [44].

The main problem with using CTCs as a so-called liquid biopsy is the fact that, at present, there is no 
standard definition for the identification of CTCs [73]. Currently, the CELLSEARCH system, based on immunomagnetic EpCAM capturing, is the only system for CTC enumeration in BC approved by the U.S. Food and Drug Administration [7]. However, despite the prognostic impact of CTC counts in $\mathrm{BC}$, it has been shown that this procedure is not able to detect the entire, highly heterogeneous population of CTCs, including slCTCs and CTCs in EMT [74, 75]. Despite the prognostic impact of CTC counts, it is indispensable to characterize these cells, which might complement these studies by improving the overall detection rate as well as sensitivity and thus permit the assessment of genomic markers in CTCs of patients with $\mathrm{BC}$, as recently published [45].

Although we and others, by using molecular methods, have already characterized the heterogeneous CTC populations in primary $\mathrm{BC}$ before adjuvant therapy [7, 33, 37, 38, 76, 77], in few studies have researchers evaluated the presence, not the characteristics, of CTCs after adjuvant therapy, resulting in a positivity rate of $22-34 \%$ [17, 20, 78]. Furthermore, in the neoadjuvant setting, the number of circulating epithelial cells was mostly used for monitoring the effect of chemotherapy after every cycle of treatment [23, 24]. To the best of our knowledge, our present study is the first in which CTCs have been characterized so comprehensively before and after NACT. In contrast to DTCs, most of the CTCs before therapy, present in about $24 \%$ of the patients and reflecting the heterogeneous CTC population, were eliminated by the given therapy. Although we cannot definitively prove that all residual CTCs were stem cell-like and EMT-like, molecular marker expression might allow characterization of them as stem cell-like. In addition, $72 \%$ of the residual cells were characterized as ERCC1-positive, indicating therapy-resistant tumor cell populations. Interestingly, seven of these eight patients had been treated with taxanes or anthracyclines, which were shown to eradicate DTCs in a Norwegian study [13]. The fact that ERCC1-positive CTCs were present after these therapies might indicate that these cells survived treatment. This knowledge might help clinicians to decide more precisely about further secondary treatment options in the future. However, CTCs and slCTCs before as well as after therapy did not significantly correlate with decreased PFS or OS, as described in the abovementioned studies. On one hand, follow-up time might have been too short to see an effect on outcome; on the other hand, factors determining if single tumor cells form metastasis have not been identified yet. In this regard, it has been demonstrated that CTCs can be detected after more than 20 years in patients with BC without any sign of relapse [79].

\section{Secondary treatment options}

Tumor stem cells are well known to be resistant to various chemotherapeutic agents and radiotherapy [80]. In this context, Creighton et al. reported supportive evidence that the residual breast tumor tissue cell populations surviving after letrozole or docetaxel were enriched for subpopulations of cells with both tumor-initiating and mesenchymal features [41]. Thus, additional therapeutic strategies are urgently needed to prevent relapse of the disease. In this regard, signaling pathways that maintain cancer stem cells are attractive targets for these therapies. One example is everolimus (RAD001), an oral inhibitor of mammalian target of rapamycin acting downstream of the PI3K/AKT pathway, which was shown to have effective inhibitory effects on cancer stem cells in vitro and in vivo, and combination treatment with RAD001 and docetaxel or trastuzumab has been reported to be effective in refractory metastatic BC [81]. Li et al. demonstrated that remaining tumorigenic cells after chemotherapy had unique properties of enhanced self-renewal as demonstrated by formation of mammospheres and increased propensity for tumor formation. In addition, lapatinib did not lead to an increase in these tumorigenic cells; thus, in combination with conventional therapy, specific pathway inhibitors may provide a therapeutic strategy for eliminating these cells to decrease recurrence and improve long-term survival [82]. Concerning HER2, a recently published study suggested that the clinical efficacy of adjuvant trastuzumab may relate to the ability of this agent to target the cancer stem cell population in a process that does not require HER2 gene amplification [83]. These results are partly comparable with ours because we observed clearance of slCTCs after NACT in some patients who received trastuzumab, lapatinib, or bevacizumab, whereas patients who did not receive these combinations had slCTCs left after therapy (data not shown). These observations have to be interpreted with caution, and more patients have to be followed to prove whether this observation holds true. Further promising agents that are thought to attack BC stem cells are salinomycin, where treatment resulted in the loss of expression of $\mathrm{BC}$ stem cells [84], and a new synthetic curcumin analogue against ALDH1 and glycogen synthase kinase-3 $\beta$ [85]. In the future, targeting the tumor microenvironment, such as by interrupting the immune cells (e.g., myeloid-derived suppressor cells) and cytokines [e.g., interleukin (IL)-6, IL-8] as well as the immune checkpoints [programmed cell death protein 1/programmed cell death ligand 1 (PD1/ PDL1)], may provide additional new tools for immunological targeting of cancer stem cells [86].

\section{Conclusions}

CTCs were eradicated effectively by NACT; however, CTCs detected after treatment seemed to be associated 
with tumor cells showing tumor stem cell characteristics as well as resistant tumor cell populations, which might indicate worse outcomes in the future. These patients might benefit from additional second-line treatment protocols that attack BC stem cells. In contrast, DTCs were not targeted effectively by NACT and were still present in about $20 \%$ of patients after therapy. Nevertheless, DTCs were not associated with worse outcomes, probably due to clodronate intake as a secondary treatment option for the eradication of DTCs.

\section{Additional file}

Additional file 1: Exact numbers of patients who had the different tests before and after NACT.(PDF $34 \mathrm{~kb}$ )

\begin{abstract}
Abbreviations
ALDH1: aldehyde dehydrogenase 1; BC: breast cancer; BM: bone marrow; CTC: circulating tumor cell; DCIS: ductal carcinoma in situ; DTC: disseminated tumor cell; EMT: epithelial-mesenchymal transition; EpCAM: epithelial cell adhesion molecule; ER: estrogen receptor; ERCC1: excision repair crosscomplementing rodent repair deficiency, complementation group 1; HER2: human epidermal growth factor receptor 2; HR: hazard ratio; IHC: immunhistochemistry; IL: interleukin; MUC1: mucin 1, cell surface associated; NACT: neoadjuvant chemotherapy; OR: odds ratio; OS: overall survival; pCR: pathological complete response; PFS: progression-free survival; PI3K: phosphoinositide 3-kinase; pNR: pathological no response; pPR: pathological partial response; PR: progesterone receptor; RT-PCR: reverse transcription polymerase chain reaction; sICTC: stem cell-like circulating tumor cell; TNM: tumor, node, metastasis stage; TWIST1: Twist-related protein 1; ZOL: zoledronic acid.
\end{abstract}

\section{Competing interests}

The authors declare that they have no competing interests.

\section{Authors' contributions}

All authors have made substantive intellectual contributions to this study and gave final approval of the manuscript version to be published. All authors agree to be accountable for all aspects of the work in ensuring that questions related to the accuracy or integrity of any part of the work are appropriately investigated and resolved. Each author participated sufficiently in the work to take public responsibility for appropriate portions of the content. SKB: conception and design of the study, acquisition of data, analysis and interpretation of data, drafting of the manuscript, and revision of the manuscript critically for important intellectual content. AKB: analysis and interpretation of data, drafting of the manuscript, and revision of the manuscript critically for important intellectual content. LK: acquisition of data and revision of the manuscript critically for important intellectual content. KR: acquisition of data and revision of the manuscript critically for important intellectual content. TK: analysis and interpretation of data and revision of the manuscript critically for important intellectual content. RK: analysis and interpretation of data and revision of the manuscript critically for important intellectual content. $\mathrm{OH}$ : conception and design of the study, acquisition of data, analysis and interpretation of data, drafting of the manuscript, and revision of the manuscript critically for important intellectual content. All authors read and approved the final manuscript.

\section{Author details}

'Department of Gynecology and Obstetrics, University Hospital Essen, University of Duisburg-Essen, Hufelandstrasse 55, D-45122 Essen, Germany. ${ }^{2}$ ACOMED Statistik, Fockestrasse 57, D-04275 Leipzig, Germany.

Received: 9 October 2015 Accepted: 29 January 2016

Published online: 12 February 2016

\section{References}

1. Mauri D, Pavlidis N, loannidis JP. Neoadjuvant versus adjuvant systemic treatment in breast cancer: a meta-analysis. J Natl Cancer Inst. 2005:97:188-94.

2. Kaufmann M, von Minckwitz G, Bear HD, Buzdar A, McGale P, Bonnefoi H, et al. Recommendations from an international expert panel on the use of neoadjuvant (primary) systemic treatment of operable breast cancer: new perspectives 2006. Ann Oncol. 2007;18:1927-34.

3. Jones RL, Smith IE. Neoadjuvant treatment for early-stage breast cancer: opportunities to assess tumour response. Lancet Oncol. 2006;7:869-74.

4. Symmans WF, Peintinger $F$, Hatzis $C$, Rajan $R$, Kuerer $H$, Valero V, et al. Measurement of residual breast cancer burden to predict survival after neoadjuvant chemotherapy. J Clin Oncol. 2007;25:4414-22.

5. Bonnefoi H, Litière S, Piccart M, MacGrogan G, Fumoleau P, Brain E, et al. Pathological complete response after neoadjuvant chemotherapy is an independent predictive factor irrespective of simplified breast cancer intrinsic subtypes: a landmark and two-step approach analyses from the EORTC 10994/BIG 1-00 phase III trial. Ann Oncol. 2014;25:1128-36.

6. Banys M, Krawczyk N, Fehm T. The role and clinical relevance of disseminated tumor cells in breast cancer. Cancers. 2014;6:143-52.

7. Joosse SA, Gorges TM, Pantel K. Biology, detection, and clinical implications of circulating tumor cells. EMBO Mol Med. 2014;7:1-11.

8. Braun S, Vogl FD, Naume B, Janni W, Osborne MP, Coombes RC, et al. A pooled analysis of bone marrow micrometastasis in breast cancer. $N$ Engl J Med. 2005:353:793-802.

9. Janni W, Vogl FD, Wiedswang G, Synnestvedt M, Fehm T, Jückstock J, et al. Persistence of disseminated tumor cells in the bone marrow of breast cancer patients predicts increased risk for relapse - a European pooled analysis. Clin Cancer Res. 2011;17:2967-76.

10. Tjensvoll K, Oltedal S, Heikkilä R, Kvaløy JT, Gilje B, Reuben JM, et al. Persistent tumor cells in bone marrow of non-metastatic breast cancer after primary surgery are associated with inferior outcome. BMC Cancer. 2012;12:190.

11. Mathiesen RR, Borgen E, Renolen A, Løkkevik E, Nesland JM, Anker G, et al Persistence of disseminated tumor cells after neoadjuvant treatment for locally advanced breast cancer predicts poor survival. Breast Cancer Res. 2012;14:117.

12. Gruber I, Fehm T, Taran FA, Wallwiener M, Hahn M, Wallwiener D. Disseminated tumor cells as a monitoring tool for adjuvant therapy in patients with primary breast cancer. Breast Cancer Res Treat. 2014;144:353-60.

13. Synnestvedt M, Borgen E, Wist E, Wiedswang G, Weyde K, Risberg T, et al. Disseminated tumor cells as selection marker and monitoring tool for secondary adjuvant treatment in early breast cancer: descriptive results from an intervention study. BMC Cancer. 2012;12:616.

14. Stathopoulou A, Vlachonikolis I, Mavroudis D, Perraki M, Kouroussis C, Apostolaki S, et al. Molecular detection of cytokeratin-19-positive cells in the peripheral blood of patients with operable breast cancer: evaluation of their prognostic significance. J Clin Oncol. 2002;20:3404-12.

15. Xenidis N, Perraki M, Kafousi M, Apostolaki S, Bolonaki I, Stathopoulou A, et al. Predictive and prognostic value of peripheral blood cytokeratin-19 mRNA-positive cells detected by real-time polymerase chain reaction in node-negative breast cancer patients. J Clin Oncol. 2006;24:3756-62.

16. Ignatiadis M, Perraki M, Apostolaki S, Politaki E, Xenidis N, Kafousi M, et al. Molecular detection and prognostic value of circulating cytokeratin-19 messenger RNA-positive and HER2 messenger RNA-positive cells in the peripheral blood of women with early-stage breast cancer. Clin Breast Cancer. 2007;7:883-9.

17. Xenidis N, Ignatiadis M, Apostolaki S, Perraki M, Kalbakis K, Agelaki S, et al. Cytokeratin-19 mRNA-positive circulating tumor cells after adjuvant chemotherapy in patients with early breast cancer. J Clin Oncol. 2009;27:2177-84.

18. Bidard FC, Mathiot C, Delaloge S, Giachetti S, de Cremoux P, Marty M, et al. Single circulating tumor cell detection and overall survival in nonmetastatic breast cancer. Ann Oncol. 2010;21:729-33.

19. Lucci A, Hall CS, Lodhi AK, Bhattacharyya A, Anderson AE, Xiao L, et al. Circulating tumour cells in non-metastatic breast cancer: a prospective study. Lancet Oncol. 2012;13:688-95.

20. Rack B, Schindlbeck C, Jückstock J, Andergassen U, Hepp P, Zwingers T et al Circulating tumor cells predict survival in early average-to-high risk breast cancer patients. J Natl Cancer Inst 2014;106:dju066. doi: 10.1093/jnci/dju066. 
21. Hartkopf AD, Taran FA, Wallwiener M, Hagenbeck C, Melcher C, Krawczyk N, et al. The presence and prognostic impact of apoptotic and nonapoptotic disseminated tumor cells in the bone marrow of primary breast cancer patients after neoadjuvant chemotherapy. Breast Cancer Res. 2013;15:R94.

22. Wiedswang G, Borgen E, Schirmer C, Kåresen R, Kvalheim G, Nesland JM, et al. Comparison of the clinical significance of occult tumor cells in blood and bone marrow in breast cancer. Int J Cancer. 2006;118:2013-9.

23. Pachmann K, Camara $O$, Kavallaris $A$, Schneider U, Schünemann S, Höffken K. Quantification of the response of circulating epithelial cells to neoadjuvant treatment for breast cancer: a new tool for therapy monitoring. Breast Cancer Res. 2005;7:975-9.

24. Camara O, Rengsberger M, Egbe A, Koch A, Gajda M, Hammer U, et al. The relevance of circulating epithelial tumor cells (CETC) for therapy monitoring during neoadjuvant (primary systemic) chemotherapy in breast cancer. Ann Oncol. 2007;18:1484-92.

25. Rack B, Juckstock J, Genss EM, Schoberth A, Schindlbeck C, Strobl B, et al. Effect of zoledronate on persisting isolated tumour cells in patients with early breast cancer. Anticancer Res. 2010;30:1807-13.

26. Hoffman O, Aktas B, Goldnau C, Oberhoff C, Kimmig R, Kasimir-Bauer S. Effect of ibandronate on disseminated tumor cells in the bone marrow of patients with primary breast cancer: a pilot study. Anticancer Res. 2011;31:3623-8

27. Solomayer EF, Gebauer G, Hirnle P, Janni W, Lück HJ, Becker S, et al. Influence of zoledronic acid on disseminated tumor cells in primary breast cancer patients. Ann Oncol. 2012;23:2271-7.

28. Banys M, Solomayer EF, Gebauer G, Janni W, Krawczyk N, Lueck HJ, et al. Influence of zoledronic acid on disseminated tumor cells in bone marrow and survival: results of a prospective clinical trial. BMC Cancer. 2013;13:480.

29. DETECT III - A Multicenter, Randomized, Phase III Study to Compare Standard Therapy Alone Versus Standard Therapy Plus Lapatinib in Patients With Initially HER2-negative Metastatic Breast Cancer and HER2-positive Circulating Tumor Cells. https://clinicaltrials.gov/ct2/show/NCT01619111. Accessed 5 Feb 2016.

30. Koch J, Rack B, Messina C, Müller V, Fehm T, Janni W, et al. Die TREAT-CTC Studie (EORTC 90091-10093/BIG 1-12) - ein neuer Ansatz zur Therapie von zirkulierenden Tumorzellen (CTCS) beim frühen Mammakarzinom [abstract]. Senologie. 2014;11:A64.

31. Balic $M$, Lin $H$, Young $L$, Hawes $D$, Giuliano A, McNamara G, et al. Most early disseminated cancer cells detected in bone marrow of breast cancer patients have a putative breast cancer stem cell phenotype. Clin Cancer Res. 2006;12:5615-21.

32. Reuben JM, Lee BN, Gao H, Cohen EN, Mego M, Giordano A, et al. Primary breast cancer patients with high risk clinicopathologic features have high percentages of bone marrow epithelial cells with ALDH activity and CD44 ${ }^{+}$CD24 ${ }^{\text {lo }}$ cancer stem cell phenotype. Eur J Cancer. 2011;47:1527-36.

33. Kasimir-Bauer S, Hoffmann O, Wallwiener D, Kimmig R, Fehm T. Expression of stem cell and epithelial-mesenchymal transition markers in primary breast cancer patients with circulating tumor cells. Breast Cancer Res. 2012;14:R15.

34. Aktas B, Tewes M, Fehm T, Hauch S, Kimmig R, Kasimir-Bauer S. Stem cell and epithelial-mesenchymal transition markers are frequently expressed in metastatic breast cancer patients with circulating tumor cells. Breast Cancer Res. 2009;11:R46.

35. Deng G, Krishnakumar S, Powell AA, Zhang H, Mindrinos MN, Telli ML, et al. Single cell mutational analysis of PIK3CA in circulating tumor cells an metastases in breast cancer reveals heterogeneity, discordance and mutation persistence in cultured disseminated tumor cells from bone marrow. BMC Cancer. 2014;14:456.

36. Fehm T, Krawczyk N, Solomayer EF, Becker-Pergola G, Dürr-Störzer $\mathrm{S}$ Neubauer $\mathrm{H}$, et al. ERalpha-status of disseminated tumour cells in bone marrow of primary breast cancer patients. Breast Cancer Res. 2008;10:R76.

37. Fehm T, Hoffmann O, Aktas B, Becker S, Solomayer EF, Wallwiener D, et al. Detection and characterization of circulating tumor cells in blood of primary breast cancer patients by RT-PCR and comparison to status of bone marrow disseminated cells. Breast Cancer Res. 2009;11:R59.

38. Lianidou ES, Mavroudis D, Georgoulias V. Clinical challenges in the molecular characterization of circulating tumour cells in breast cancer. $\mathrm{Br}$ J Cancer. 2013;108:2426-32.

39. Krawczyk N, Meier-Stiegen F, Banys M, Neubauer H, Ruckhaeberle E, Fehm T. Expression of stem cell and epithelial-mesenchymal transition markers in circulating tumor cells of breast cancer patients. Biomed Res Int. 2014;2014:415721.
40. Hartkopf AD, Banys M, Meier-Stiegen F, Hahn M, Röhm C, Hoffmann J, et al. The HER2 status of disseminated tumor cells in the bone marrow of early breast cancer patients is independent from primary tumor and predicts higher risk of relapse. Breast Cancer Res Treat. 2013;138:509-17.

41. Creighton CJ, Li X, Landis M, Dixon JM, Neumeister VM, Sjolund A, et al. Residual breast cancers after conventional therapy display mesenchymal as well as tumor-initiating features. Proc Natl Acad Sci U S A. 2009;106: 13820-5.

42. Bidard FC, Belin L, Delaloge S, Lerebours F, Ngo C, Reyal F, et al. Timedependent prognostic impact of circulating tumor cells detection in non-metastatic breast cancer: 70-month analysis of the REMAGUS02 study. Int J Breast Cancer. 2013;2013:130470.

43. Riethdorf S, Müller V, Zhang L, Rau T, Loibl S, Komor M, et al. Detection and HER2 expression of circulating tumor cells: prospective monitoring in breast cancer patients treated in the neoadjuvant GeparQuattro trial. Clin Cancer Res. 2010;16:2634-45.

44. Fei F, Du Y, Di G, Wu J, Shao Z. Are changes in circulating tumor cell (CTC) count associated with the response to neoadjuvant chemotherapy in local advanced breast cancer? A meta-analysis. Oncol Res Treat. 2014:37:250-4.

45. Andreopoulou E, Yang LY, Rangel KM, Reuben JM, Hsu L, Krishnamurthy S, et al. Comparison of assay methods for detection of circulating tumor cells (CTCS) in metastatic breast cancer (MBC): AdnaGen AdnaTest BreastCancer Select/Detect versus Veridex Cell Search system. Int J Cancer. 2012;130:1590-7.

46. Müller V, Riethdorf S, Rack B, Janni W, Fasching PA, Solomayer E, et al. Prognostic impact of circulating tumor cells assessed with the Cell Search System and AdnaTest Breast in metastatic breast cancer patients: the DETECT study. Breast Cancer Res. 2012;14:R118.

47. AGO Mamma. http://www.ago-online.de/de/infothek-fuer-aerzte/ leitlinienempfehlungen/mamma/.

48. Phase I/I-Studie zur neoadjuvanten Chemotherapie mit nicht-pegyliertem liposomalem Doxorubicin, Paclitaxel und Lapatinib bei Patientinnen mit HER2-überexprimierenden, primärem Mammakarzinomen. EudraCT identifier 2007-000924-42. https://www.clinicaltrialsregister.eu/ctr-search/trial/2007000924-42/DE\#E. Accessed 5 Feb 2016.

49. de Azambuja E, Holmes AP, Piccard-Gebhart M, Holmes E, Di Cosimo S, Swaby RF, et al. Lapatinib with trastuzumab for HER2-positive early breast cancer (NeoALTTO): survival outcomes of a randomised, open-label, multicentre, phase 3 trial and their association with pathological complete response. Lancet Oncol. 2014;15:1137-46.

50. Untch M, Loibl S, Bischoff J, Eidtmann H, Kaufmann M, Blohmer JU, et al. Lapatinib versus trastuzumab in combination with neoadjuvant anthracycline-taxane-based chemotherapy (GeparQuinto, GBG 44): a randomised phase 3 trial. Lancet Oncol. 2012;13:135-44.

51. http://www.awmf.org/awmf-online-das-portal-der-wissenschaftlichenmedizin/awmf-aktuell.html.

52. Arbeitsgemeinschaft Gynäkologische Onkologie. Empfehlungen gynäkologische Onkologie Kommission Mamma. http://www.ago-online.de/ en/guidelines-mamma/march-2015/pdf: Adjuvant Cytotoxic and Targeted Therapy. Accessed 5 Feb 2016.

53. Sinn HP, Schmid H, Junkermann H, Huober J, Leppien G, Kaufmann M, et al. Histologic regression of breast cancer after primary (neoadjuvant) chemotherapy [in German]. Geburtshilfe Frauenheilkd. 1994;54:552-8.

54. Fehm T, Braun S, Müller V, Janni W, Gebauer G, Marth C, et al. A concept for the standardized detection of disseminated tumor cells in bone marrow of patients with primary breast cancer and its clinical implementation. Cancer. 2006;107:885-92.

55. Kasimir-Bauer S, Mayer S, Bojko P, Borquez D, Neumann R, Seeber S. Survival of tumor cells in stem cell preparations and bone marrow of patients with high-risk or metastatic breast cancer after receiving dose-intensive or highdose chemotherapy. Clin Cancer Res. 2001;7:1582-8.

56. Borgen E, Naume B, Nesland JM, Kvalheim G, Beiske K, Fodstad O, et al. Standardization of the immunocytochemical detection of cancer cells in BM and blood: I. Establishment of objective criteria for the evaluation of immunostained cells. Cytotherapy. 1999;1:377-88.

57. Hauch S, Zimmermann S, Lankiewicz S, Zieglschmid V, Böcher O, Albert WH. The clinical significance of circulating tumour cells in breast cancer and colorectal cancer patients. Anticancer Res. 2007;27:1337-41.

58. Kuhlmann JD, Wimberger P, Aktas B, Buderath P, Kimmig R, Kasimir-Bauer S. The persistence of ERCC1-positive circulating tumor cells predicts worse prognosis in patients with primary ovarian cancer. Clin Chem. 2014;60:1282-9. 
59. Ellis IO, Cornelisse CJ, Schnitt SJ, Sasco AJ, Sastre-Garau X, Kaaks R, et al. Invasive breast carcinoma. In: Tavassoli FA, Devilee P, editors. World Health Organization classification of tumours: tumours of the breast and female genital organs. Lyon, France: IARC Press; 2003. p. 13-59.

60. Sobin LH, Wittekind C. TNM classification of malignant tumours. 6 th ed. New York: Wiley-Liss; 2002

61. Lal P, Salazar PA, Hudis CA, Ladanyi M, Chen B. HER-2 testing in breast cancer using immunohistochemical analysis and fluorescence in situ hybridization: a single-institution experience of 2,279 cases and comparison of dual-color and single-color scoring. Am J Clin Pathol. 2004;121:631-6.

62. Zentrum für Krebsregisterdaten. http://www.rki.de/Krebs/DE/Content/ Krebsarten/Brustkrebs/brustkrebs_node.html. Accessed 5 Feb 2016.

63. von Minckwitz G, Blohmer JU, Costa SD, Denkert C, Eidtmann H, Eiermann W, et al. Response-guided neoadjuvant chemotherapy for breast cancer. J Clin Oncol. 2013:31:3623-30.

64. Fehm T, Becker S, Becker-Pergola G, Sotlar K, Gebauer G, Dürr-Störzer S, et al. Presence of apoptotic and nonapoptotic disseminated tumor cells reflects the response to neoadjuvant systemic therapy in breast cancer. Breast Cancer Res. 2006;8:R60.

65. Ye X, Weinberg RA. Epithelial-mesenchymal plasticity: a central regulator of cancer progression. Trends Cell Biol. 2015;25:675-86.

66. Synnestvedt M, Borgen E, Schlichting E, Schirmer CB, Renolen A, Giercksky $\mathrm{KE}$, et al. Disseminated tumour cells in the bone marrow in early breast cancer: morphological categories of immunocytochemically positive cells have different impact on clinical outcome. Breast Cancer Res Treat. 2013:138:485-97.

67. Krawczyk N, Hartkopf A, Banys M, Meier-Stiegen F, Staebler A, Wallwiener M, et al. Prognostic relevance of induced and spontaneous apoptosis of disseminated tumor cells in primary breast cancer patients. BMC Cancer. 2014;14:394

68. Mathiesen RR, Fjelldal R, Liestøl K, Due EU, Geigl JB, Riethdorf S, et al. Highresolution analyses of copy number changes in disseminated tumor cells of patients with breast cancer. Int J Cancer. 2012;131:405-15.

69. Møller EK, Kumar P, Voet T, Peterson A, Van Loo P, Mathiesen RR, et al. Nextgeneration sequencing of disseminated tumor cells. Front Oncol. 2013;3:320.

70. Abraham BK, Fritz P, McClellan M, Hauptvogel P, Athelogou M, Brauch H Prevalence of $\mathrm{CD} 44^{+} / \mathrm{CD} 24^{-/ \text {low }}$ cells in breast cancer may not be associated with clinical outcome but may favor distant metastasis. Clin Cancer Res. 2005:11:1154-9.

71. Naume B, Synnestvedt M, Falk RS, Wiedswang G, Weyde K, Risberg T, et al. Clinical outcome with correlation to disseminated tumor cell (DTC) status after DTC-guided secondary adjuvant treatment With docetaxel in early breast cancer. J Clin Oncol. 2014;32:3848-57.

72. Hoffmann O, Schroer-Zuendorf IA, Kasimir-Bauer S, Oberhoff C, Kimmig R, Heubner M. Evaluation of the prognostic significance of disseminated tumor cells in the bone marrow of primary, non-metastatic breast cancer patients after a 7-year follow-up. Arch Gynecol Obstet. 2015;292:1117-25.

73. Alix-Panabières $C$, Pantel K. Technologies for detection of circulating tumor cells: facts and vision. Lab Chip. 2014;14:57-62.

74. Cristofanilli M, Budd GT, Ellis MJ, Stopeck A, Matera J, Miller MC, et al. Circulating tumor cells, disease progression, and survival in metastatic breast cancer. N Engl J Med. 2004;351:781-91.

75. Sieuwerts AM, Kraan J, Bolt J, van der Spoel P, Elstrodt F, Schutte M, et al. Anti-epithelial cell adhesion molecule antibodies and the detection of circulating normal-like breast tumor cells. J Natl Cancer Inst. 2009;101:61-6.

76. Barrière G, Riouallon A, Renaudie J, Tartary M, Rigaud M. Mesenchymal characterization: alternative to simple CTC detection in two clinical trials. Anticancer Res. 2012:32:3363-9.

77. Barrière G, Riouallon A, Renaudie J, Tartary M, Rigaud M. Mesenchymal and stemness circulating tumor cells in early breast cancer diagnosis. BMC Cancer. 2012;12:114

78. Xenidis N, Vlachonikolis I, Mavroudis D, Perraki M, Stathopoulou A, Malamos $\mathrm{N}$, et al. Peripheral blood circulating cytokeratin-19 mRNA-positive cells after the completion of adjuvant chemotherapy in patients with operable breast cancer. Ann Oncol. 2003;14:849-55.

79. Meng S, Tripathy D, Frenkel EP, Shete S, Naftalis EZ, Huth JF, et al. Circulating tumor cells in patients with breast cancer dormancy. Clin Cancer Res. 2004;10:8152-62.

80. Monteiro J, Fodde R. Cancer stemness and metastasis: therapeutic consequences and perspectives. Eur J Cancer. 2010;46:1198-203.
81. Zhang J, Zhang XB, Liu Y, Liu JJ, Zhang MS. Effects of an mTOR inhibitor RAD001 on human breast cancer stem cells in vitro and in vivo. J Clin Oncol. 2011;29 Suppl:abstr e11514.

82. Li X, Lewis MT, Huang J, Gutierrez C, Osborne CK, Wu MF, et al. Intrinsic resistance of tumorigenic breast cancer cells to chemotherapy. J Natl Cancer Inst. 2008;100:672-9.

83. Ithimakin S, Day KC, Malik F, Zen Q, Dawsey SJ, Bersano-Begey TF, et al. HER2 drives luminal breast cancer stems cells in the absence of HER2 amplification: implications for efficacy of adjuvant trastuzumab. Cancer Res. 2013;73:1635-46

84. Gupta PB, Onder T, Jiang G, Tao K, Kuperwasser C, Weinberg RA, et al. Identification of selective inhibitors of cancer stem cells by high-throughput screening. Cell. 2009;138:645-59.

85. Kesharwani RK, Srivastava V, Singh P, Rizvi SI, Adeppa K, Misra K. A novel approach for overcoming drug resistance in breast cancer chemotherapy by targeting new synthetic curcumin analogues against aldehyde

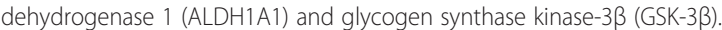
Appl Biochem Biotechnol. 2015;176:1996-2017.

86. Pan Q, Li Q, Liu S, Ning N, Zhang X, Xu Y, et al. Concise review: targeting cancer stem cells using immunologic approaches. Stem Cells. 2015;33:2085-92.

\section{Submit your next manuscript to BioMed Central and we will help you at every step:}

- We accept pre-submission inquiries

- Our selector tool helps you to find the most relevant journal

- We provide round the clock customer support

- Convenient online submission

- Thorough peer review

- Inclusion in PubMed and all major indexing services

- Maximum visibility for your research

Submit your manuscript at www.biomedcentral.com/submit
) Biomed Central 